\title{
The Effects of Armed Robbery in Nigeria
}

\author{
Abanyam, Noah Lumun, Bauchi, David, Tormusa, Daniel Orngu \\ Department of Sociology, University of Mkar-Mkar-Nigeria \\ Department of Sociology, Benue State University,Makurdi, Benue State - Nigeria \\ Department of Sociology, Federal University of Lafia,Nassaraw State- Nigeria
}

\begin{abstract}
Armed robbery is a social menace that persistently continues to retard the development of the Nigerian society. It involves stealing, during which force and violence (or the threats of violence are employed). This study investigated the effects of armed robbery on the Nigerian society. Sociological perspective is employed in analyzing the study. The findings of this study reveals that armed robbery is associated with insecurity of lives and properties, loss of human resources, reduction of the level of development, unemployment, poverty, permanent disability on the victims and wastage of state resources on security agents. It is recommended that government should increase the number of well-trained police and provide them with modern equipment. More so, all Nigerian should volunteer information that could lead to the arrest of suspected armed robbers to the police.
\end{abstract}

Key Words: Effects, Armed robbery, Nigeria, society.

\section{Introduction}

Armed robbery is a prevailing social phenomenon that negatively affects the lives and social functioning of a significant number of people in contemporary Nigerian society. It involves stealing, during which force and violence or the threat of violence are employed. Armed robbery is as old as mankind itself, and it characterizes all known societies (both developed and developing societies. However, variations exist not only from society to society but also from time to time, as well as from strict enforcement to none (Okolo, 2002). In Nigeria, daily newspaper reports, Television news headlines and radio announcements have shown that the activities of armed robbers are increasing at an alarming rate. Both the rich and the poor are always in a perpetual state of fear because nobody really knows where and when they will strike. According to Neuback (1979:301)

There is a larger increase in the incidence of robbery than for any other index offense. Robbery took place on the average on once every seventy-five seconds. Half the robberies known to the police are committed on the street, the remainder occurred within households and business establishment. Victims are unlikely to know the law violators and it is relatively easy to get away with the crime.

Armed robbery is a social problem that continued to undermine the progress of the Nigerian society since the end of the country's civil war in 1970. In response to this hazardous condition, the Nigerian military Government of General Yakubu Gawan promulgated a decree in 1970, the first ever on armed robbery in Nigeria, which stipulated and recommended death sentence by firing squad. This was followed by increase in number, size, and standard of the police force, courts and prisons. Successive Government in Nigeria has launched different campaigns and programmes such as "operation sweep", Operation scorpion" "operation flush" etc aimed at reducing the activities of armed robbers. Despite all these measures, the activities of armed robbery are on increase. It is in view of these prevailing incidences that this study is designed to ascertain the effects of armed robbery in Nigeria.

\section{Theoretical Explanation}

The cardinal theory that will be considered appropriate in analyzing this study is the sociological theory.

To, sociologists, several factors accounts for the engagement of individual in crime. One of the famous sociological explanations for criminal behaviour is anomie theory, developed by Robert Merton, which assumes that our culture places a great deal of emphasis on material success and members of the society share those materialistic values. Nevertheless, success in material terms is not readily achievable by all. However, opportunities are denied certain groups more than other - for instance, minorities and the poor. Thus, a dysfunction between cultural success goals and the availability of means to pursue them occurs. This creates stress, which takes the form of anomie, a dense of disorganization or normlessness. Those who are affected by 
anomie may engage in illegal pursuits, pursuing goals or material success by illegal means. Armed robbery in Nigeria is thus a determinant of social factors such as social mobility, culture conflict, economic competition, social stratification as well as the distribution of wealth in the society.

More so, on why individuals engaged in crime (armed robbery), sociologists believe that people could learn criminality (to be armed robbers) as they interact with one another on a daily basis, they could learn criminal behaviours just the way they learn other forms of social behaviour. Edwin Sutherland called this "differential association". In addition, sociologists argue that certain individuals are labeled or tagged "criminals" or "robbers". Such labels could make such individuals to begin to think towards such direction, as well as engage in the actual act.

\section{Effects of Armed Robbery in Nigeria}

Whatever may be the cause of armed robbery in Nigeria, and whatever nature or form or shape it may assume armed robbery is antisocial behaviour that leaves negative effects on the society and its members. A single crime, observed Skidmore and Thackeray (1982) may alter the existence of a particular family and as families become weak and filled with tension and chaos, society is injured and social life is threatened.

One of the enormous effects of armed robbery in Nigeria is that of insecurity of lives and properties. In various robbery incidences, innocents' citizens are killed, maimed to suffer while one's livelong savings and sweat are lost within a twinkle of an eye. For instance, Neubeck (1979) estimates that money and goods values at $\$ 142$ million were stolen from robbery victims in 1976. Yecho (2010:22) similarly, laments that:

A successful robbery entails the direct loss of property on an individual. Such property is transferred from the rightful owner to another Person. Most violent crime also leads to the loss of productivity through the incapacity of the victims. Most of the victims of violent crimes are incapacitated, thereby denying the society of their contribution to the output of the nation.

The killing and shooting of people most especially the youth by armed robbers reduce the size of the Nigerian working population. This automatically led to the loss of human resources (affects human resources).

Many resources are channeled to physical and psychological treatment of victims of armed robbery. The resources that would have been used to stimulate the growth of other sectors of economy are also invested in security to enable the security agents to curtail the activities of robbery.

Another significant effect of armed robbery is on the reduction of the rate or level of development. As a result of high prevalence incidences of armed robbery in Nigeria. People are always in a perpetual state of fear because of constant robbery attacks. Thus, many foreign investors are afraid of committing their resources to operate in industries that would employed many millions of the unemployed Nigerians. This consequently retards the development of the Nigerian society.

In addition, armed robbery causes unemployment because robbing of industries and other government establishments (companies) results to retrenchment of workers because of the inability to pay workers salary.

Armed robbery increases the level of poverty in Nigeria. For instance, in a situation where armed robbers killed the breadwinner of the family. The robbers will subject the whole family into poverty (absolute poverty) and thus increase the level of poverty in the society. Again, Yecho (2010:23) summarized these effects thus:

There is also the social cost dimension. People no longer go out at specific periods to interact and carry out social activities/functions. Every body becomes suspicious of one another. In a society where everyone is suspicious of each other, where movement is restricted for the fear of criminal victimization, there can be no meaningful development and progress. Finally, there is also a physical cost dimension to incidences of violent crimes. Robbery and kidnap could result to death or permanent disability of the victim.

\section{Conclusion and Recommendations}

This study affirmed that armed robbery is hazardous and holds many negative effects on individuals, families and the society as a whole. The study reveals the effects of armed robbery on Nigerian society such as insecurity of lives and properties, loss of human resources, reduction of the level of development, unemployment, permanent disability on the victims and poverty. There is an agent need for the Nigerian government to take a decisive step to tackle the problem of armed robbery and other related criminal activities across the country.

In view of the foregoing discussions, the following recommendations are made:

1. Government should increase (recruit) the number of well-trained police and provide them with modern technical equipments such as helicopters, effective communication devices, surveillance camerals, sophisticated armed and ammunitions, trained dogs, adequate patrol vehicles, etc. This will burst their 
morale in combating armed robbers more effectively. If such equipments are provided and the police salaries and allowances are increase, the police will be motivated to combat crime assertively.

2. Government should periodically organize seminars and workshops for police. These series of seminars and workshops will provide opportunity for police officers to enrich their knowledge and learn new ideas on the modern technique of combating crimes. Government should also sponsor some police officers to undergo training in advanced countries. This will enable them to acquire mastery of their jobs.

3. Moreover, all Nigerians citizens should volunteer information that could lead to arrest of suspected armed robbers (Criminals). The police on the other hand must establish a friendly relationship with the public so that members of the public can be able to volunteer information confidentially. Such volunteers or agents must not be exposed by the police because they may be targeted by armed criminal gangs. Security involves both the police (other security agents) and the public.

\section{References}

[1]. Neubeck, K.F. (1979). Social Problems. New York: Foresman and Company.

[2]. Okolo, G.U. (2002). Social Work: An Introductory Analysis. Calabar: University of Calabar Press.

[3]. Skidmore, B.A. and Thackeray, M.G. (1982). Introduction to Social Work. New Jersey: Prentice-Hall.

[4]. Yecho, J.I. (2010). Violent Crime Wave in Contemporary Nigeria: The Case of Benue State" in Benue Journal of Sociology Vol. 3 No. 1 Makurdi: Selfers Academic Press Ltd.

[5]. Sutherland, E. (1949) White Collor Crime. New York: Dryden Press.

[6]. Merton, R.K. (1964) Social Theory and Social structure. New York: Free Press. 